\title{
A BRIEF BIOGRAPHICAL APPRECIATION OF DR. EDMUND ALEXANDER PARKES, M.D., F.R.S.
}

By

\author{
Colonel J. P. CROWDY
}

Born at Bloxham near Oxford on 20 Mar 1819, Edmund Parkes was one of two brothers in a respected professional family. He went to school in London, at Christ's Hospital and thereafter studied medicine at University College and University College Hospital, graduating M.B. in 1841 .

Despite his later and much longer connections with the Army his actual military career was brief but not uneventful. After being gazetted as an Assistant Surgeon in 1842 he joined the 84th (York and Lancaster) Regiment and left England for service in India and Burma: During rather less than 3 years overseas he made exemplary use of his time for medical investigation in both Madras and the Tenasserim province of Burma. Returning to London in $\mathbf{1 8 4 5}$ he entered private practice although it is reported that his writing and his continued investigations did not allow him much time to amass a lucrative consulting practice. Nevertheless, in 1849 he was appointed Professor of Clinical Medicine at his old medical school, University College Hospital, where he worked and taught, with only one major break, until his appointment to the newly formed Army Medical School in 1860. The 2 year hiatus in his clinical career was the result of his selection by the War Office, to set up and manage Renkioi Hospital in the Dardanelles from 1855-56. His detailed account of the site and its selection, the hospital, its design and management make an entrancing tale. The hospital itself, probably the first ever wholly prefabricated building, was designed in collaboration with the famous engineer, Isambard Kingdom Brunel. It was transported to Turkey in modular form so that were a ship to be lost at sea the hospital could still function, albeit on a smaller scale. Altogether Parkes superintended 1331 admissions but with the end of the Crimean war in sight the hospital never worked to its full capacity. The most frequent cause of admission was spotted typhus, associated mainly with the verminous troops from the Land Transport Corps. Parkes wrote of them as " hastily enlisted and numbering many boys and men considerably past their prime . . . . quite unfitted to cope with the hardships of the Crimean winter". With the same perspicacity that characterised his later writings Parkes said of his charges "I know that no men are so manageable as English soldiers when properly treated and when spirits are kept from them ".

Returned to his consulting and hospital duties in London, it was not long (1860) before Parkes forsook clinical medicine to launch the science of hygiene from the newly created chair at the Army Medical School. His appointment as foundation professor of hygiene was notable in two ways: first in respect to the chair itself; it was the first to be established in Britain, if not in the rest of the world. Second, because the wisdom of those who appointed him, among whom stand out Sidney Herbert (later Lord Herbert of Lea) and Florence Nightingale, was so amply justified over the next 16 years. It was from the Army Medical School, first at Fort Pitt and later at Netley, that Parkes created his international reputation. Others have extolled the merits of his outstanding textbook "A manual of practical hygiene"; his experiments, writings and lectures were as remarkable for their wide variety of subject matter as for their erudition and masterly 
simplicity. For 16 years he was the undoubted leader and champion of the developing science of hygiene; indeed he could be said to be its creator.

Ill health interrupted, but did not prevent Dr. Parkes' continuing outflow of writings. Even in 1875 when the advance of pulmonary tuberculosis forced him to leave Netley and retire to his nearby home in Bitterne, he did not stop work. Right up to the time of his death, on 15th March 1876, he was occupied with scientific writings, among which was the almost completed Harveian oration he was destined never to deliver.He was buried beside his wife-who had predeceased him three years earlier-in Solihull Church with only a simple inscription to record his life and death.

Parkes died at the peak of his fame. The obituaries that flowed in bore tribute to a great man whose international reputation was at an exceptional level. Outstanding among them was that from Baron J. Mundy, professor of military hygiene at Vienna, whose closing words were "All the Armies of the Continent should lower their creped standards on parade because Edmund Parkes, the founder and best teacher of military hygiene, the friend and benefactor of every soldier, is no more".

In the years immediately after Parkes' death many were the honours bestowed on his name. A memorial museum was established to which Queen Victoria herself contributed $£ 50$; a marble bust was put up in the library of University College Hospital; a prize fund was established at the Army Medical School (now the Royal Army Medical College), and in the early years of this century his name was chosen as one of the 21 pioneers of public health whose portraits in stone decorate the frieze outside the London School of Hygiene and Tropical Medicine.

In conclusion, the Army can look back with satisfaction on its wisdom in appointing to the first chair of hygiene a man who did more than any other, past or present, to improve and safeguard the soldier's health.

\section{BIOGRAPHICAL REFERENCES}

Aitken, W. (1876). "In Memoriam". An address on opening the 32nd (not 36th) session of the Army Medical School. 3 April 1876. Bell \& Bain. Glasgow.

Bellott, H. H. (1929). "University College London, 1826 ". University of London Press Ltd. London. Pp. 273-275.

Dickinson, C. J., HiLl, G. J. M. and John, H. T. (1951). " The North London or University College Hospital ". Univ. Coll. Mag. 36, 101-144.

Dictionary of National Biography (1895). (Contributed by Surgeon Captain W. W. Webb). Vol. 43, 294-296. Smith Elder \& Co. London.

JENNER, Sir William (1876). "Observations on the work and character of the late E. A. Parkes, M.D., F.R.S.: Being the supplement to Dr. Parkes's Harveian oration ". Brit. med. J. ii, 33.

Lewis, M. M. (1958). "The speciality of Army health". Publ. Hlth (Lond.) 72, 107-116.

Mundy, J. (1876). " Parkes". Wien. med. Wschr. 26, 330-331.

Obituary. (1876). Medical Times \& Gazette. 25 March 1876. Pp. 348-349.

OBITUARY. (1876). Lancet i, 480-482.

Obituary (1876). Brit. med. J. i, 397.

OrSBORn, J. (1876). "In Memorian, Edmund Alexander Parkes". An address to the Southampton Medical Society. 2 May 1876.

PARkes, E. A. (1857). " Report on the formation and general management of Renkioi Hospital on the Dardanelles-Turkey". War Department. London.

Simon, Sir John (1897). "English Sanitary Institutions". 2nd ed. John Murray. London. P. 245.

WALker, M. E. M. (1930). "Pioneers of Public Health. The story of some benefactors of the human race ". Oliver \& Boyd. London. Pp. 126-136. 


\section{EDMUND ALEXANDER PARKES}

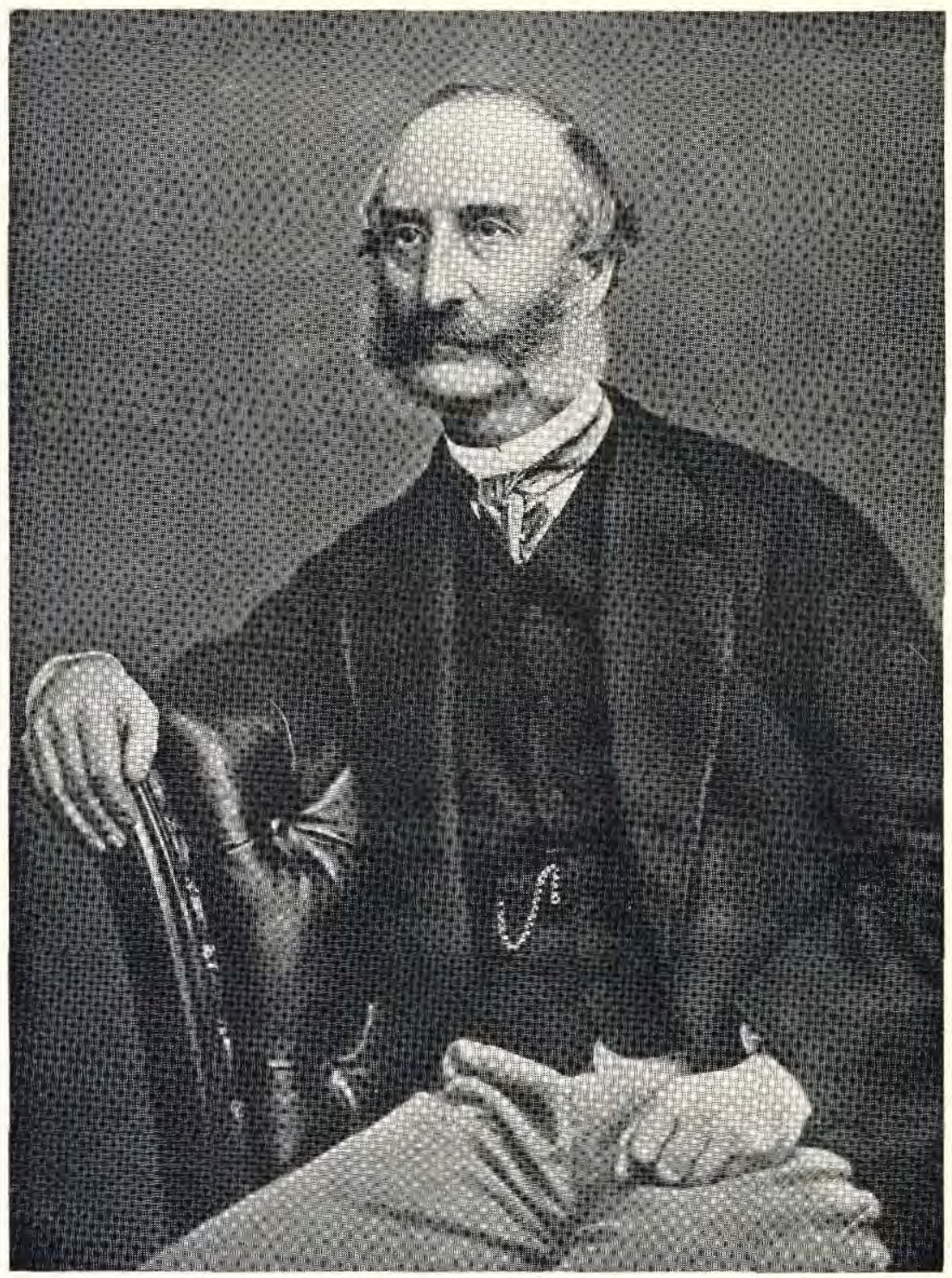

$(1819-1876)$

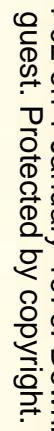

